\section{Japan's cloning ban will still allow stem cell experiments}

Tokyo

Japan's parliament, the Diet, is expected to approve a new law later this month prohibiting the reimplantation into the uterus of human clones, chimaeras, or 'hybrids' - but allowing experimentation with cloned embryos, subject to strict guidelines.

The text of the law has been drawn up by the Science and Technology Agency (STA) after consultation with an expert panel. In contrast to the regulations covering federally funded research in the United States, some forms of nuclear transfer will be allowed.

The relatively limited scope of the legal restrictions has surprised members of the committees drafting the bill as well as some observers in Tokyo. In particular, it appears that the reimplantation of clones that have been created using cells from human embryos - defined as an 'unborn' human being - will not be banned, but merely subject to guidelines and a review of experimental protocols.

STA officials say that the new bill does justice to both science and ethics by prohibiting human cloning without preventing potential opportunities that may emerge from stem cell and human embryo research. Guidelines covering the latter are to be released later this month by the Council of Science and Technology, an advisory body close to STA.

But critics argue that the new law could open a 'back door' for human cloning research. And members of the expert panel say that the distinction made by STA between the nuclear transfer from cells of 'born' and 'unborn' human beings "had never been discussed at the panel".

Sources in Tokyo say that interventions by politicians and the medical community, worried that tight regulations could limit future economic opportunities for Japanese companies in such areas as stem cell research, have greatly influenced the final shape of the bill.

Motoya Katsuki, a professor in embryology at the Institute of Medical Research at the University of Tokyo and a member of the cloning and human embryo research expert panels, accepts that using guidelines rather than legal constraints in areas of science that are changing fast will make regulation more flexible. But he argues that the resulting regulatory framework is clumsy and may lack credibility in the eyes of the public. Robert TriendI

\title{
Space researchers protest at 'disruptive' export controls
}

\section{Washington}

US space scientists are becoming increasingly alarmed about strict new government export control policies introduced in response to Congressional concern over the sales of missile technology to China.

A Hungarian scientist, for example, who built an instrument for a satellite being developed by Stanford University, was denied access to inspect his own instrument after it entered the United States.

"It flies in the face of reason," says Bradford Parkinson of Stanford, chairman of the advisory council to the space agency NASA.

The new regulations place an "impossible burden on most universities" working on spacecraft missions, according to Claude Canizares of the Massachusetts Institute of Technology (MIT), who chairs the National Academy of Sciences' Space Studies Board.

In 1998 Congress transferred authority over satellite technology exports from the Commerce Department to the State Department, which administers the International Traffic in Arms Regulations (ITAR). The shift has effectively placed researchers working on scientific spacecraft in the same category as munitions exporters.

Although ITAR exempts scientific research, NASA policy directives issued last month do not. This has caused widespread concern among space scientists who say they are now unsure whether foreign-born graduate students are allowed to work on satellite hardware and data without first obtaining an export licence.

Canizares aired his concerns at a meeting last week of the NASA Advisory Council. His move prompted other academic scientists on the panel to share horror stories about projects mired in red tape and legal uncertainty.

Steven Squyres of Cornell University, who plays a leading role in the US-French Mars exploration programme, said that ITAR issues are particularly irksome in NASA projects that are trying to operate in a 'better, faster, cheaper' mode. "The more international we get, the more of a problem it's going to be," he told the advisory council.

Canizares and Eugene Skolnikoff of MIT, who chairs an academy committee on international space programmes, wrote last month to National Research Council chairman Bruce Alberts, suggesting that the academy conduct a study of the ITAR problem.

Other groups, including the Association of American Universities and the Council on Governmental Relations (COGR), a Washington-based association of research universities, have also taken up the cause, and have been working with several universities -

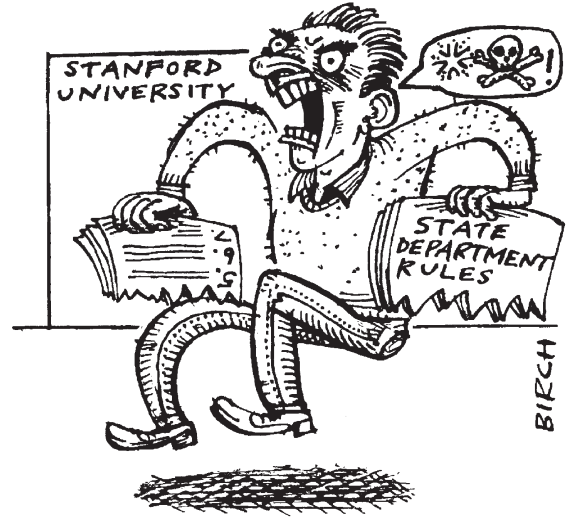

IN INTERNATIONAL SPACE PROJECTS, NOBODY CAN HEAR YOU SCREAM...

such as Stanford, MIT, the University of California, and the University of Maryland on a plan of action. The NASA Advisory Council also formed a subcommittee last week to look into the issue, led by Canizares.

Tony DeCrappeo of COGR says that the problems being experienced by NASAfunded researchers will probably extend to other agencies, including the Department of Energy and the Department of Defense. But he believes that an answer lies within reach if existing laws are interpreted properly. "I think the exception [for researchers] as written in the ITAR is probably okay," he says, meaning that no new legislation would have to be written to exempt scientists.

But all agree that a clarification of the policy has to come from the top. A similar confusion over regulations governing foreign access to very-high-speed integratedcircuit technology in the 1980s was settled after years of debate by a national security directive from President Ronald Reagan.

NASA Administrator Daniel Goldin, who heard the scientists' complaints at the meeting, urged them not to "get preachy," and to respect legitimate national security concerns - particularly when the current political climate in Washington favours a 'get tough' attitude toward the leaking of hightech secrets. Congress recently passed a law preventing NASA from sending more money to Russia for the international space station project unless questions about transfer of missile technology to Iran are resolved.

"It is a very difficult environment now," said Goldin, who is nevertheless eager to reassure the university community, which he envisages will play a larger role in NASA-sponsored research as the agency's budget increases. "The transformation of NASA cannot occur without a stronger relationship with universities," he told the advisory council.

Tony Reichhardt 